\title{
Utjecaj vježbanja na snagu stiska šake i antropometrijske karakteristike kod žena u menopauzi - longitudinalna studija
}

\section{Effect of exercise on handgrip and anthropometric characteristics in postmenopausal women - longitudinal study}

\author{
Sara Frank Radošević, Gordana Starčević-Klasan*
}

\begin{abstract}
Sažetak. Cilj: Ciljevi su ovog istraživanja ispitati utjecaj devetomjesečnog programa vježbanja na snagu stiska šake i antropometrijske parametre žena u menopauzi. Ispitanici i metode: Istraživanje je obuhvatilo 122 žene u menopauzi. Ispitanice su zatim podijeljene u dvije skupine: skupina koja vježba $(n=94)$ i kontrolna skupina $(n=28)$. Svaka je ispitanica izmjerena dva puta, na početku programa vježbanja od devet mjeseci i na kraju, dok su ispitanice kontrolne skupine izmjerene samo jednom. Svakoj su ispitanici izmjereni tjelesna težina, tjelesna visina, indeks tjelesne mase (engl. Body Mass Indeks; BMI), opseg struka i bokova, omjer opsega struka i bokova (engl. Waist hip ratio; WHR), kao i snaga stiska desne i lijeve šake. Rezultati: Prema rezultatima ovog istraživanja ispitanice koje su uključene u program vježbanja pokazuju značajnu razliku BMI $(p<0,05)$ i WHR $(p<0,05)$ u odnosu na mjerenje provedeno na početku vježbanja. Također, rezultati snage stiska šake pokazuju statistički značajne razlike između prvog i drugog mjerenja $(p<0,05)$. Prosječna vrijednost stiska desne šake na kraju vježbanja je $26,03 \pm 5,04 \mathrm{~kg}$, što je značajno veće u odnosu na prvo mjerenje $24,51 \pm 5,68 \mathrm{~kg}$. Isto tako, snaga stiska lijeve šake nakon drugog mjerenja iznosila je $24,7 \pm 5,11 \mathrm{~kg}$, što je značajno veće u odnosu na prvo mjerenje 23,39 $\pm 5,77$ kg. Zaključak: Aktivno vježbanje dovodi do poboljšanja snage stiska obiju šaka nakon završenog programa vježbanja u trajanju od devet mjeseci. Kod svih je ispitanica pronađena značajna razlika BMI i WHR na kraju provedenog programa vježbanja, što upućuje na pozitivan utjecaj vježbi otpora na antropometrijske karakteristike žena u menopauzi.
\end{abstract}

Ključne riječi: indeks tjelesne mase; menopauza; omjer opsega struka i bokova; snaga stiska šake

Abstract. Aim: The present study examined the effects of a 9 months exercise program on the handgrip strength and anthropometric parameters in postmenopausal women. Participants and methods: The study included 122 postmenopausal women divided into the exercise group $(n=94)$ and the control group $(n=28)$. Each participant was assessed prior and after 9 months of rhe exercise program performed. The control group was tested only once. Anthropometric parameters including body height, body weight, body mass index (BMI), waist and hip circumferences, and waist to hip ratio (WHR), as well as the handgrip strength were measured. Results: According to the results of this study, the participants included in the exercise program showed a significant difference between BMI $(p<0.05)$ and WHR $(p<0.05)$ compared to the measurement performed at the beginning of exercise. Also, statistically significant differences $(p<0.05)$ were found in the handgrip strength between the first and second measurements. The right handgrip strength at the end of the exercise program was $26.03 \pm 5.04 \mathrm{~kg}$, which is significantly higher compared to the first measurement of $24.51 \pm 5.68 \mathrm{~kg}$. In addition, the left handgrip strength after the second measurement was $24.7 \pm 5.11 \mathrm{~kg}$, which is significantly higher compared to the first measurement of $23.39 \pm 5.77$ $\mathrm{kg}$. Conclusion: Results suggest that a 9-month exercise program leads to an improvement in the handgrip strength. Furthermore, a significant difference between BMI and WHR was found in all participants at the end of the exercise program, which indicates a positive impact of resistance exercise on the anthropometric characteristics of postmenopausal women.

Key words: body mass index; hand strength; menopause; waist-hip ratio
Katedra za temeljne medicinske znanosti, Fakultet zdravstvenih studija Sveučilišta u Rijeci, Rijeka, Hrvatska

\section{*Dopisni autor:}

Izv. prof. dr. sc. Gordana Starčević-Klasan, dr. med.

Fakultet zdravstvenih studija Sveučilišta u Rijeci, V. C. Emina 5, 51000 Rijeka, Hrvatska E-mail: gordanask@uniri.hr

http://hrcak.srce.hr/medicina 


\section{UVOD}

Menopauza predstavlja kraj reproduktivnog razdoblja u životu svake žene. Fiziološki menopauzu karakterizira smanjenje produkcije spolnih hormona što dovodi do tjelesnih i funkcionalnih promjena u tijelu žene. Te promjene uključuju povećanje tjelesne težine i preraspodjelu masnog tkiva u predjelu trupa što dovodi do rasta trbuha te do povećane pojave kroničnih i kardiovaskularnih bolesti.

Snaga stiska šake značajno je veća u skupini žena u menopauzi koje su bile uključene u devetomjesečni program vježbanja. Snaga stiska šake opada sa starenjem i kod starijih osoba može biti pokazatelj ukupne mišićne snage i funkcije.

Nezdrave životne navike, prvenstveno manjak fizičke aktivnosti i nepravilna prehrana kod žena u menopauzi, dovode do smanjene kvalitete živo$t^{1,2}$. Starenje značajno utječe na smanjenje mišićne mase i gubitak mišićne snage što uzrokuje ograničenje tjelesnih pokreta i povećanu opasnost od pada i prijeloma ${ }^{3,4}$. Smanjenje mišićne mase očituje se kao smanjenje broja mišićnih vlakana i smanjenje njihovog poprečnog promjera, što se naziva i mišićnom atrofijom ${ }^{5}$. Osim strukturalnih promjena mišića uslijed starenja istovremeno se događaju promjene i na staničnoj razini, kao što su smanjenje mitohondrijske funkcije, povećanje oksidativnog stresa, smanjenje aktivnosti satelitskih stanica i povećanja pojave upalnih procesa ${ }^{6-8}$. Uz pojavu mišićne atrofije tijekom starenja dolazi i do smanjenja mišićne snage. Mišićna snaga značajno opada nakon 50 . godine života, te se smatra da to smanjenje iznosi 2 - 4 \% godišnje. Smatra se da je gubitak mišićne snage tri puta veći nego stupanj mišićne atrofije ${ }^{9,10}$. Stoga je vrlo važna procjena snage mišića kod žena u menopauzi. Mjerenje snage stiska šake jednostavna je metoda mjerenja snage mišića koja se vrlo često koristi u kliničkoj praksi. Neke su studije pokazale da je snaga stiska šake povezana s funkcijom mišića donjih udova i učestalošću prijeloma kod starijih osoba ${ }^{11}$. Debljina je jedan od čimbenika koji do- datno utječe na smanjenje mišićne mase i snage te je povezana sa smanjenom osjetljivošću na inzulin, mitohondrijalnom disfunkcijom i poremećajem regeneracijskog kapaciteta skeletnih mišića ${ }^{12,13}$. Osim toga debljina je povezana s pojavom određenih bolesti kao što su šećerna bolest, povećan krvni tlak, koronarna bolest srca, moždani udar i neki oblici karcinoma, kao što su karcinomi dojke i debelog crijeva ${ }^{14,15}$. Danas se kao općeniti pokazatelji debljine najviše koriste neke od antropometrijskih mjera kao što su BMI, opseg struka, opseg bokova i WHR. Kod žena u menopauzi karakteristično je nakupljanje masnog tkiva u području struka i bokova, stoga se u procjeni debljine kao objektivnija metoda koristi mjerenje WHR. Vrijednost WHR veća od 0,8 za žene predstavlja povećani zdravstveni rizik od kardiovaskularnih bolesti, hipertenzije, šećerne bolesti i mnogih drugih oboljenja ${ }^{16}$. Istraživanje iz 2019. godine provedeno u Hrvatskoj na uzorku od 799 žena u rasponu od 20 do 85 godina pokazalo je da se opseg struka i bokova povećavao sa starenjem, što ukazuje na povećan zdravstveni rizik, osobito žena u dobi od 60 do 85 godina ${ }^{17}$. Stoga je edukacija i usvajanje zdravih navika žena u menopauzi izuzetno važna. Redovita fizička aktivnost i zdrave životne navike pozitivno utječu na mnoge aspekte života žena u menopauzi, kao što su spavanje, depresija, povećanje tjelesne težine, smanjenje izvođenja pokreta i pojavu kardiovaskularnih bolesti ${ }^{18}$. Povećanje tjelesne aktivnosti, posebno vježbi koje su usmjerene na izdržljivost, fleksibilnost i ravnotežu, smanjuje rizik od pada, a samim time i rizik od prijeloma kuka ili kralješka, te utječe na dužu neovisnost starijih osoba od pomoći druge osobe $^{19}$.

Studije pokazuju pozitivan utjecaj aerobnih vježbi i vježbi snage ne samo na BMI i WHR nego i na snagu skeletnih mišića kod žena prije menopauze i u menopauzi ${ }^{20-24}$. Cilj je ovog istraživanja prikazati utjecaj vježbi otpora na antropometrijske parametre, kao što su BMI i WHR kod žena u menopauzi na početku vježbanja te nakon devet mjeseci redovite tjelesne aktivnosti. Ovim se istraživanjem također ispitao utjecaj redovitog vježbanja na snagu stiska šake kod žena na početku i na kraju programa vježbanja. 


\section{ISPITANICE I METODE}

\section{Ispitanice}

$\mathrm{U}$ istraživanju su sudjelovale 94 žene u menopauzi koje su bile uključene u redoviti program vježbanja te 28 žena u menopauzi u kontrolnoj skupini. Ispitanice su uključene u vježbanje u sklopu projekta „Tjelesnom aktivnošću i pravilnom prehranom u borbi protiv osteoporoze i šećerne bolesti" koji je financiran od Grada Rijeke, a provodi se na Medicinskom fakultetu Sveučilišta u Rijeci, uz suradnju Fakulteta zdravstvenih studija Sveučilišta u Rijeci. Ispitanice su umirovljenice regrutirane iz Udruge umirovljenika. Vježbanje se odvijalo na lokalitetima mjesnih odbora Kantrida, Turnić, Bulevard, Krnjevo i Kostrena u više termina, jutarnjim i popodnevnim. Ispitanice su bile uključene u vježbanje tri puta tjedno po 60 minuta tijekom devet mjeseci, od rujna 2014. do lipnja 2015. godine. Na svim su ispitanicama provedena dva mjerenja, jedno na početku programa vježbanja i drugo na kraju programa vježbanja. Ispitanice kontrolne skupine imale su samo jedno mjerenje i nisu bile uključene u program vježbanja. Ispitanice koje su bile uključene u prilagođeni program vježbanja, vježbale su uz nadzor liječnika i fizioterapeuta uključenih u provođenje projekta, koji su i izvršili sva mjerenja na njima. Istraživanje je odobrilo Etičko povjerenstvo Medicinskog fakulteta u Rijeci i sve su ispitanice potpisale informirani pristanak za sudjelovanje u istraživanju.

\section{Program vježbanja}

Vježbanje je uvijek počinjalo zagrijavanjem u trajanju od 10 minuta uz vježbe dubokog disanja i istezanja glavnih skupina mišića ekstremiteta i trupa. Nakon toga se nastavilo s vježbama jačanja uz upotrebu utega, trake za vježbanje, pilateslopte i štapa u stojećem i ležećem položaju. Zadnjih 5-10 minuta treninga uključivalo je vježbe istezanja mišića ekstremiteta i trupa. Sve skupine ispitanica koje su bile uključene u program vježbanja vježbale su pod nadzorom liječnika i fizioterapeuta uključenih u projekt.

\section{Metode}

Za mjerenje tjelesne mase koristila se digitalna vaga, a za mjerenje tjelesne visine stadiometar. Iz dobivenih vrijednosti tjelesne težine i visine izračunat je BMI kao težina u kilogramima podijeljena s kvadratom visine u metrima. Ispitanice su na osnovi dobivenih BMI vrijednosti kategorizirane $u$ pet skupina: pothranjenost $\left(B M I<20 \mathrm{~kg} / \mathrm{m}^{2}\right)$, idealna tjelesna težina (BMI $\left.=20-24,9 \mathrm{~kg} / \mathrm{m}^{2}\right)$, prekomjerna tjelesna težina $\left(\mathrm{BMI}=25-29,9 \mathrm{~kg} / \mathrm{m}^{2}\right)$, pretilost $\left(\mathrm{BMI}=30-43,9 \mathrm{~kg} / \mathrm{m}^{2}\right)$, i jaka pretilost $\left(\mathrm{BMI}>44 \mathrm{~kg} / \mathrm{m}^{2}\right)$.

Za mjerenje opsega struka i bokova koristila se centimetarska traka. Opseg struka mjerio se na sredini spojnice između krila bočne kosti i posljednjeg rebra, dok se opseg bokova mjerio preko sredine glutealne regije. Za izračun WHR dobivena se vrijednost opsega struka podijelila $\mathrm{s}$ vrijednosti opsega bokova. Ispitanice se na osnovi dobivenih vrijednosti mogu svrstati u tri skupine: niski zdravstveni rizik (WHR $<0,80$ ), umjereni zdravstveni rizik (WHR 0,81 do 0,85), visok zdravstveni rizik (WHR >0,86).

Za ispitivanje snage stiska desne i lijeve šake koristio se ručni dinamometar (Citec dynamometer, CIT Technics, Groningen, The Netherlands). Snaga stiska šake ispitivala se u sjedećem položaju s ramenom $u$ adukciji i neutralnoj rotaciji, laktom u fleksiji od $90^{\circ}$ te u neutralnoj poziciji podlaktice i ručnog zgloba. Nakon zauzimanja pravilnog položaja ispitanica je stisnula dinamometar svom snagom te se snaga stiska šake očitala na mjernom instrumentu (kg - kilogram). Stisak svake šake testiran je naizmjenično tri puta, a za konačni se rezultat uzela srednja vrijednost svih dobivenih mjerenja. Mjerenje se provelo zasebno za obje šake.

\section{Statistika}

Prikupljeni podatci obrađivani su pomoću programa Microsoft Excel (Microsoft Office) i Statistica 13.3.0, Tibico. Podatci su prikazani apsolutnim i relativnim vrijednostima, aritmetičkom sredinom i standardnom devijacijom ili medijanom i rasponom. Aritmetičkom sredinom i standardnom devijacijom prikazani su antropometrijski podatci (visina, tjelesna masa, indeks tjelesne mase) i omjer struka i bokova i stisak šake, medijanom i rasponom prikazana je dob ispitanika, a apsolutnim i relativnim vrijednostima kategorije uhranjenosti i zdravstvenog rizika. Korišten je Kolmogorov-Smir- 
novljev test za testiranje normalne raspodjele podataka, a za dobivanje statistički značajne razlike između prvog i drugog mjerenja Student t-test za zavisne uzorke, a između ispitivane skupine i kontrolne Student t-test za nezavisne uzorke. Za usporedbu frekvencija prvog i drugog mjerenja korišten je McNemarov test, a za usporedbu frekvencija ispitivane i kontrolne skupine hi-kvadrat test $\left(c^{2}\right)$. Razina statističke značajnosti je $p<0,05$.

\section{REZULTATI}

U ovoj longitudinalnoj studiji sudjelovale su 122 ispitanice, u ispitivanoj skupini njih 94, a u kontrolnoj 28. Medijan dobi ispitanica uključenih $u$ vježbanje je 73 godine (51 - 95), a kontrolne skupine 69,5 godina $(62-82)$. Dobivene vrijednosti BMI pokazuju statistički značajnu razliku $(p<0,05)$ između prvog mjerenja $\left(27,71 \pm 4,46 \mathrm{~kg} / \mathrm{m}^{2}\right)$ i drugog mjerenja $\left(27,08 \pm 4,31 \mathrm{~kg} / \mathrm{m}^{2}\right)$ kod ispitanica koje su uključene u program vježbanja. Kontrolna skupina imala je prosječan BMI $27,21 \pm 4,07 \mathrm{~kg} / \mathrm{m}^{2}$ te nije pronađena statistički značajna razlika u us- poredbi s ispitivanom skupinom žena (tablica 1 ). Prikaz vrijednosti BMI prema pet kategorija pokazuje da se najveći broj žena ispitivane skupine nalazi u kategoriji idealne tjelesne mase $(44,68 \%$ i $43,62 \%)$, a isto tako je i s kontrolnom skupinom $(39,29 \%)$. U kontrolnoj je skupini veći postotak ispitanica u kategoriji prekomjerne tjelesne mase $(32,14 \%)$ u odnosu na ispitivanu skupinu žena (25,53\% i $23,40 \%)$ (tablica 2$)$.

Usporedba prosječne vrijednosti WHR ispitivane skupine pokazala je da postoji statistički značajna razlika između prvog i drugog mjerenja (0,93 \pm $0,08$ vs $0,92 \pm 0,08, p<0,05)$. Prosječna vrijednost WHR u kontrolnoj skupini iznosila je 0,88 \pm 0,11 , što je manje u odnosu na dobivene vrijednosti $u$ ispitivanoj skupini $(p<0,05)$ (tablica 1 ). Analiza raspodjele ispitanica po zdravstvenom riziku pokazuje da se najveći broj ispitanica ispitivane skupine nalazi u visokom zdravstvenom riziku. Nakon drugog mjerenja broj ispitanica u visokom zdravstvenom riziku smanjio se $(81,91 \%$ vs $74,47 \% p=0,023$ ) (tablica 3 ).

Tablica 1. Prikaz aritmetičkih sredina i standardnih devijacija antropometrijskih karakteristika ispitanica na početku vježbanja (1. mjerenje), nakon devetomjesečnog programa vježbanja (2. mjerenje), i kontrolne skupine

\begin{tabular}{|l|r|r|r|r|}
\cline { 2 - 6 } \multicolumn{1}{c|}{} & $\begin{array}{c}\text { 1. mjerenje } \\
\text { (n=94) }\end{array}$ & $\begin{array}{c}\text { 2. mjerenje } \\
\text { (n=94) }\end{array}$ & $\begin{array}{c}\text { Kontrolna skupina } \\
\text { (n= 28) }\end{array}$ & $\mathbf{p < 0 , 0 5}$ \\
\hline Visina $(\mathrm{cm})$ & $161,89 \pm 6,43$ & $160,70 \pm 6,38$ & $162,38 \pm 4,69$ & a \\
\hline Težina (kg) & $72,57 \pm 12,07$ & $69,94 \pm 11,76$ & $71,68 \pm 10,50$ & a \\
\hline BMI (kg/m) & $27,71 \pm 4,46$ & $27,08 \pm 4,31$ & $27,21 \pm 4,07$ & a \\
\hline Struk (cm) & $95,23 \pm 10,88$ & $93,16 \pm 10,53$ & $89,18 \pm 8,73$ & a \\
\hline Bokovi (cm) & $103,14 \pm 8,95$ & $101,05 \pm 8,85$ & $102,21 \pm 6,96$ & a \\
\hline WHR & $093 \pm 0,08$ & $0,92 \pm 0,08$ & $0,88 \pm 0,11$ & a b \\
\hline
\end{tabular}

*Vrijednosti prikazane u stupcima predstavljaju aritmetičku sredinu \pm standardnu devijaciju.

BMI - (body mass index) indeks tjelesne mase; WHR - (waist to hip ratio) omjer opsega struka i bokova

a - značajna razlika između 1. i 2. mjerenja

b - značajna razlika između kontrolne skupine i 1. i 2. mjerenja

Tablica 2. Podjela ispitanica u pet kategorija BMI na početku vježbanja (1. mjerenje), nakon devetomjesečnog programa vježbanja (2. mjerenje), i kontrolne skupine

\begin{tabular}{|c|c|c|c|c|c|c|c|c|c|}
\hline & \multicolumn{2}{|c|}{ 1. mjerenje } & \multicolumn{2}{|c|}{ 2. mjerenje } & \multirow{2}{*}{$\begin{array}{c}\text { McNemarov } \\
(p)\end{array}$} & \multicolumn{2}{|c|}{ Kontrolna skupina } & \multirow{2}{*}{$\begin{array}{c}\chi^{2} \\
(p)^{*}\end{array}$} & \multirow{2}{*}{$\begin{array}{c}\chi^{2} \\
(p)^{* *}\end{array}$} \\
\hline & $\mathbf{n}$ & $\%$ & $\mathbf{n}$ & $\%$ & & $\mathbf{n}$ & $\%$ & & \\
\hline Pothranjenost & 19 & 20,21 & 25 & 26,60 & 0,077 & 7 & 25,00 & 0,779 & 0,539 \\
\hline Idealna tjelesna masa & 42 & 44,68 & 41 & 43,62 & 1,000 & 11 & 39,29 & 0,773 & 0,850 \\
\hline Prekomjerna tjelesna masa & 24 & 25,53 & 22 & 23,40 & 0,752 & 9 & 32,14 & 0,419 & 0,493 \\
\hline Pretilost & 8 & 8,51 & 5 & 5,32 & 0,248 & 1 & 3,57 & 0,641 & 0,903 \\
\hline Jaka pretilost & 1 & 1,06 & 1 & 1,06 & - & - & - & & - \\
\hline
\end{tabular}

*1. mjerenje i kontrolna skupina; ${ }^{* *} 2$. mjerenje i kontrolna skupina 
Tablica 3. Podjela ispitanica u tri kategorije zdravstvenog rizika na početku vježbanja (1. mjerenje), nakon devetomjesečnog programa vježbanja (2. mjerenje), i kontrolne skupine

\begin{tabular}{|c|c|c|c|c|c|c|c|c|c|}
\hline \multirow{2}{*}{ WHR } & \multicolumn{2}{|c|}{ 1. mjerenje } & \multicolumn{2}{|c|}{ 2. mjerenje } & \multirow{2}{*}{$\begin{array}{c}\text { McNemarov } \\
(p)\end{array}$} & \multicolumn{2}{|c|}{ Kontrolna skupina } & \multirow{2}{*}{$\begin{array}{c}\chi^{2} \\
(p)^{*}\end{array}$} & \multirow{2}{*}{$\begin{array}{c}\chi^{2} \\
(p)^{* *}\end{array}$} \\
\hline & $\mathbf{n}$ & $\%$ & $\mathbf{n}$ & $\%$ & & $\mathbf{n}$ & $\%$ & & \\
\hline Nizak zdravstveni rizik $(\leq 0,8)$ & 3 & 3,19 & 6 & 6,38 & 0,248 & 10 & 35,72 & $<0,001$ & $<0,001$ \\
\hline $\begin{array}{l}\text { Srednji zdravstveni rizik } \\
(0,81-0,85)\end{array}$ & 14 & 14,89 & 18 & 19,15 & 0,343 & 3 & 10,71 & 0,803 & 0,452 \\
\hline Visok zdravstveni rizik $(\geq 0,86)$ & 77 & 81,91 & 70 & 74,47 & 0,023 & 15 & 53,57 & 0,005 & 0,061 \\
\hline
\end{tabular}

"1. mjerenje i kontrolna skupina; "*2. mjerenje i kontrolna skupina

Tablica 4. Prikaz vrijednosti snage stiska desne i lijeve šake kod ispitanica na početku vježbanja (1. mjerenje), nakon devetomjesečnog programa vježbanja (2. mjerenje), i kontrolne skupine

\begin{tabular}{|l|c|c|c|c|c|c|}
\hline \multirow{2}{*}{} & \multicolumn{2}{c|}{ Desna šaka } & \multicolumn{2}{c|}{ Lijeva šaka } & \multicolumn{2}{c|}{ Kontrolna skupina } \\
\cline { 2 - 8 } & 1. mjerenje & 2. mjerenje & 1. mjerenje & 2. mjerenje & Desna šaka & Lijeva šaka \\
\hline Srednja vrijednost $(\mathrm{kg})$ & 24,51 & $26,03^{\text {a }}$ & 23,39 & $24,70^{\text {a }}$ & 24,56 & 23,63 \\
\hline Standardna devijacija & 5,68 & 5,04 & 5,77 & 5,11 & 4,08 & 3,70 \\
\hline
\end{tabular}

a - značajna razlika između 1. i 2. mjerenja

Mjerenja snage stiska šake pokazala su statistički značajnu razliku između prvog i drugog mjerenja i desne i lijeve šake $(p<0,05)$. Prosječna vrijednost stiska desne šake nakon prvog mjerenja bila je $24,51 \pm 5,68 \mathrm{~kg}$, a nakon drugog mjerenja 26,03 \pm $5,04 \mathrm{~kg}$. Prosječna vrijednost snage stiska lijeve šake iznosila je $23,39 \pm 5,77$ kg nakon prvog mjerenja te $24,70 \pm 5,11 \mathrm{~kg}$ nakon drugog mjerenja (tablica 4). Rezultati kontrolne skupine pokazali su da ne postoji statistički značajna razlika između snage stiska desne $(p=0,208)$ i snage stiska lijeve šake $(p=0,059)$ u odnosu na ispitivanu skupinu žena.

\section{RASPRAVA}

Provedeno istraživanje, koje je prvo takve vrste na području grada Rijeke, imalo je za cilj utvrditi utjecaj vježbi otpora na antropometrijske karakteristike i snagu stiska šake kod žena u menopauzi. Istraživanje je pokazalo statistički značajno bolje rezultate antropometrijskih parametara kod žena nakon završenog programa vježbanja u odnosu na mjerenja koja su provedena na početku ispitivanja. Nakon devetomjesečnog programa vježbanja došlo je do smanjenja BMI u odnosu na vrijednosti BMI kod istih ispitanica na početku vježbanja. Srednja vrijednost BMI kod svih je ispitanica oko 27, što ih svrstava u skupinu prekomjerne tjelesne težine, međutim analiza BMI po
Vježbanje ima pozitivan utjecaj na antropometrijske parametre kod žena u menopauzi. Nakon devetomjesečnog programa vježbanja došlo je do smanjenja BMI u odnosu na vrijednosti na početku vježbanja. Rezultati WHR pokazuju smanjenje broja ispitanica $u$ skupini visokog zdravstvenog rizika u drugom mjerenju, a povećanja u skupinama srednjeg i niskog zdravstvenog rizika.

kategorijama pokazuje da se najveći postotak žena, 44,68\% nalazi u kategoriji idealne tjelesne mase nakon prvog mjerenja i 43,62 \% žena nakon drugog mjerenja. Također je pronađen povećan postotak ispitanica u kategoriji pothranjenosti nakon drugog mjerenja $(26,60 \%)$ u odnosu na prvo mjerenje $(20,21 \%)$. Ta se promjena može objasniti smanjenjem razine estrogena koje utječe na smanjenje ukupne tjelesne vode, mišićne mase i mase organa tijekom menopauze. Poznato je da se kod žena u menopauzi smanjuje odgovor skeletnih mišića na anaboličke podražaje, što dovodi do smanjenja mišićne mase ${ }^{25-27}$. Indeks tjelesne mase antropometrijska je mjera koja procjenjuje tjelesnu mast na temelju tjelesne težine u odnosu na visinu ${ }^{17}$. Epidemiološka istraživanja pokazala su da je BMI između 25 i 30 povezan s umjerenim porastom smrtnosti, dok je 
BMI 30 ili više povezan sa stopom smrtnosti 50 do $100 \%$ višom nego kod osoba s BMI od 20 do 25. Nedostatak BMI kao pokazatelja pretilosti jest u tome što debljinu ne određuje povećana tjelesna masa nego povećan udio masti u tjelesnoj masi, te stoga u mnogim slučajevima ne predstavlja pouzdanu metodu procjene pretilosti. To se najbolje uočava kod žena u menopauzi kada su vrijednosti BMI od 25 za prekomjernu težinu i BMI od 30 za pretilost previsoke za njih jer im se tjelesni sastav mijenja sa starenjem ${ }^{28,29}$. Starenjem žene gube koštanu i mišićnu masu, a masno tkivo čini veći udio tjelesne težine. Masno se tkivo kao visceralna masnoća raspoređuje u području trbuha uslijed nedostatka estrogena i povezana je s poremećajem metaboličkih funkcija, povećanim kolesterolom, lipoproteinima manje gustoće i otpornosti na inzulin ${ }^{30}$. U prilog tome govore dobivene vrijednosti WHR u ovom istraživanju. Mjerenje WHR predstavlja objektivnu metodu procjene stupnja pretilosti. Vrijednost WHR veća od 0,8 za žene predstavlja povećan rizik od razvoja ateroskleroze i kardiovaskularnih bolesti ${ }^{31}$. Isto tako, dugotrajna je pretilost povezana sa sve slabijom snagom stiska šake tijekom starenja ${ }^{32}$. Rezultati ovog istraživanja pokazali su da je WHR kod ispitanica tijekom prvog mjerenja bio 0,93, dok su rezultati drugog mjerenja pokazali sličan rezultat od 0,92, što ih svrstava u skupinu visokog zdravstvenog rizika. Kontrolna skupina također pripada u skupinu visokog zdravstvenog rizika sa srednjom vrijednosti omjera opsega struka i bokova 0,88 . Analiza WHR po kategorijama pokazala je da je došlo do smanjenja broja ispitanica $u$ skupini visokog zdravstvenog rizika u drugom mjerenju, a povećanja u skupinama srednjeg i niskog zdravstvenog rizika, odnosno došlo je do poboljšanja rezultata kod žena nakon završenog programa vježbanja.

U provedenom istraživanju pronađena je značajna razlika u snazi desne šake nakon perioda vježbanja od devet mjeseci $(26,03 \pm 5,04$; $p<0,05) \mathrm{u}$ usporedbi s rezultatima na početku vježbanja $(24,51 \pm 5,68 ; p<0,05)$. Međutim nije pronađena statistička razlika prvog i drugog mjerenja u odnosu na kontrolnu skupinu ( $p=0,208 ; p=0,067)$. Isto tako pronađena je i značajna razlika u snazi lijeve šake nakon završenog perioda vježbanja
$(24,70 \pm 3,70 ; p<0,05)$ u odnosu na mjerenje provedeno na početku perioda vježbanja $(23,39 \pm$ $5,77 ; p<0,05)$. Dobiveni rezultati govore u prilog pozitivnog utjecaja redovitog vježbanja na snagu stiska šake kod žena u menopauzi. Većina žena uključenih u program vježbanja pokazala je poboljšanje snage stiska obiju šaka nakon završetka programa vježbanja. Holubiac i sur. navode slične rezultate u svom istraživanju koje je uključivalo žene $u$ menopauzi s osteopenijom i osteoporozom, što govori u prilog pozitivnog utjecaja vježbi uz otpor na snagu stiska šake kod žena u menopauzi ${ }^{20}$. Isto tako rezultati istraživanja Heislein i sur. pokazuju $14 \%$ poboljšanja snage stiska šake kod žena u menopauzi koje su bile uključene u program vježbanja u trajanju od osam tjedana ${ }^{21}$. Mjerenje snage stiska šake jednostavna je i učinkovita metoda procjene mišićne snage i funkcije. Kod starijih osoba snaga stiska šake daje uvid u pokretljivost i prehrambeni status osobe ${ }^{33}$. Snaga stiska šake u pozitivnoj je korelaciji s koštanom gustoćom vrata bedrene kosti, kuka i lumbalne kralježnice, odnosno što je snaga stiska šake veća, manji je rizik od prijeloma, invalidnosti i smrtno$s t^{34}$. Mjerenje snage stiska šake stoga je učinkovita metoda za procjenu snage mišića, a vježbanje snage mišića ima važnu ulogu u prevenciji i liječenju osteoporoze. Brojne studije pokazuju kako vježbanje poboljšava kardiorespiratornu funkciju i dovodi do smanjene prevalencije kroničnih bolesti kod osoba obaju spolova ${ }^{19,35,36}$. Vježbanje dovodi do povećanja veličine mišićnih vlakana i mišićne mase, poboljšava funkcionalne sposobnosti mišića i usporava smanjenje mišićne snage i infiltraciju mišića masnim tkivom ${ }^{19,37}$. Izvođenje vježbi uz otpor pokazuje posebno dobre rezultate u povećanju broja mišićnih vlakana zbog povećanja sinteze proteina u mišiću, iako poboljšanje varira prema starosti ispitanika ${ }^{38,39}$. Ne postoji metoda koja može potpuno spriječiti gubitak mišićne mase i snage uzrokovane starenjem, međutim vježbanje može značajno smanjiti utjecaj starenja na metabolizam i funkciju mišića.

\section{ZAKLJUČCI}

Rezultati našeg istraživanja, provedenog na populaciji žena u menopauzi na području grada Rijeke koje su bile aktivno uključene u organizirani 
program vježbanja, pokazuju poboljšanje snage stiska obiju šaka nakon završenog programa vježbanja u trajanju od devet mjeseci. Kod svih je ispitanica pronađena značajna razlika BMI i WHR na kraju provedenog programa vježbanja, što upućuje na pozitivan utjecaj redovitog vježbanja na antropometrijske karakteristike žena u menopauzi. Ovo je prvo takvo istraživanje u Rijeci koje je uključilo velik broj umirovljenica u organizirani program vježbanja. Provedeno istraživanje pokazalo je da period od devet mjeseci kontinuiranog vježbanja značajno povećava snagu stiska šake, što upućuje na dobar odgovor mišića na redovitu tjelesnu aktivnost. Starenje je najznačajnija varijabla koja dovodi do smanjenja mišićne snage. Stoga bi vježbanje i redovita tjelesna aktivnost trebala biti važan čimbenik zdravog starenja jer može usporiti ili u nekim slučajevima i spriječiti starenjem uzrokovani gubitak mišićne mase, mišićne snage i regenerativnog kapaciteta skeletnih mišića.

Izjava o sukobu interesa: Autori izjavljuju kako ne postoji sukob interesa.

\section{LITERATURA}

1. Rathnayake N, Alwis G, Lenora J, Lekamwasam S. Impact of health-promoting lifestyle education intervention on health-promoting behaviors and health status of postmenopausal women: a quasi-experimental study from Sri Lanka. Biomed Res Int 2019;2019:406426.

2. Shyamal Koley N. A study on handgrip strength in preand post-menopausal women of Amritsar on the basis of their rural and urban habitat. Int J Health Sci Res 2019;9:28-33.

3. Distefano G, Goodpaster BH. Effects of exercise and aging on skeletal muscle. Cold Spring Harb Perspect Med 2018;8:029785.

4. Rosenberg IH. Sarcopenia: origins and clinical relevance. J Nutr 1997;127:990-991.

5. Cruz-Jentoft AJ, Baeyens JP, Bauer JM, Boirie Y, Caderholm T, Landi F et al. Sarcopenia: European concensus of definition and diagnosis: Report of the European working group on sarcopenia in older people. Age Ageing 2010;39:412-423.

6. Fulle S, Protasi F, Di Tano G, Pietrangelo T, Beltramin A, Boncompagni $S$ et al. The contribution of reactive oxygen species to sarcopenia and muscle ageing. Exp Gerontol 2004;39:17-24.

7. Alway SE, Myers MJ, Mohamed JS. regulation of the satellite cell function in sarcopenia. Front Aging Neurosci 2014;6:246.

8. Schaap LA, Pluijm SM, Deeg DJ, Harris TB, Kritchevsky $S B, N e w m a n A B$ et al. Higher inflammatory marker levels in older persons: association with 5 -year change in muscle mass and muscle strength. J Gerontol A Biol Sci Med Sci 2009;64:1183-1189.

9. Larsson L, Li X, Frontera WR. Effects of aging on shortening velocity and myosin isoform composition in single human skeletal muscle cells. Am J Physiol 1997;272:638-649.

10. Lexell J, Taylor CC, Sjostrom M. What is the cause of the ageing atrophy? Total number, size and proportion of different fiber types studied in whole vastus lateralis muscle from 15- to 83-year-old men. I Neurol Sci 1988;84:275-294.

11. Li YZ, Zhuang HF, Cai SQ, Lin CK, Wang PW, Yan LS et al. Low grip strength is a strong risk factor of osteoporosis in postmenopausal women. Orthop Surg 2018;10:17-22.

12. Koster A, Stenholm S, Alley DE, Kim LJ, Simonsick EM, Kanaya AM et al. Body fat distribution and inflammation among obese older adults with and without metabolic syndrome. Obesity 2010;18:2354-2361.

13. Park SW, Goodpaster BH, Strotmeyer ES, Kuller LH, Broudeau $\mathrm{R}$, Kammerer $\mathrm{C}$ et al. Accelerated loss of skeletal muscle strength in older adults with type 2 diabetes: The health, aging, and body composition study. Diabetes Care 2007;30:1507-1512.

14. Eckel RH, Krauss RM. American Heart Association call to action: obesity as a major risk factor for coronary heart disease. AHA Nutrition Committee. Circulation 1998;97: 2099-2100.

15. Dennis KE. Postmenopausal women and the health consequences of obesity. J Obstet Gynecol Neonatal Nurs 2007;36:511-7.

16. Lee HJ, Hwang SY, Hong HC, RYU JY, Seo JA, Kim SG et al. Waist-to-hip ratio is a better at prediciting subclinical atherosclerosis than body mass indeks and waist circumference in postmenopausal women. Maturitas 2015;80: 323-328.

17. Doležal K, Hrženjak R. Antropometrijske izmjere u procjeni zdravlja. Sigurnost 2019;61:357-364.

18. Tan MN, Kartal M, Guldal D. The effect of physical activity and body mass. BMC Women's Health 2014;14:38.

19. Da Boit M, Sibson R, Meakin JR, Aspden RM, Theis F, Mangoni AA et al. Sex differences in the response to resistance training in older people. Physiol Rep 2016;4: 12834.

20. Holubiac IS, Grosu VT. Effect of resistance exercises on handgrip strength in postmenopausal women with osteopenia/osteoporosis. Series IX Sciences of Human Kinetics 2020;13:213-220.

21. Heislein DM, Harris BA, Jette AM. A strength training program for postmenopausal women: a pilot study. Arch Phys med Rehabil 1994;75:198-204.

22. Bergamin $M$, Gobbo S, Bullo V, Zanotto $T$, Vendramin B, Duregon $\mathrm{F}$ et al. Effects of a Pilates exercise program on muscle strength, postural control and body composition: results from a pilot study in a group of post-menopausal women. Age (Dordr) 2015;37:118.

23. Rolland $\mathrm{Y}$, Lauwers-Cances $\mathrm{V}$, Pahor M, Fillaux J, Grandjean $\mathrm{H}$, Vellas $\mathrm{B}$. Muscle strength in obese elderly women: effect of recreational physical activity in a cross-sectional study. Am J Clin Nutr 2004;79:552-557.

24. Ossowski ZM, Skrobot W, Aschenbrenner P, Cesnaitiene VJ, Smaruj M. Effects of short-term Nordic walking training on sarcopenia-related parameters in women with low bone mass: a preliminary study. Clin Interv Aging 2016;11:1763-1771. 
25. Hansen M. Female hormones: do they influence muscle and tendon protein metabolism? Proc Nutr Soc 2018; 77:32-41.

26. Sipilä S, Finni T, Kovanen V. Estrogen influences on neuromuscular function in postmenopausal women. Calcif Tissue Int 2015;96:222-233.

27. Pöllänen $E$, et al. Effects of combined hormone replacement therapy or its effective agents on the IGF-1 pathway in skeletal muscle. Growth Horm IGF Res 2010;20: 372-379.

28. Banack HR, Kaufman JS. The obesity paradox: understanding the effect of obesity on mortality among individuals with cardiovascular disease. Prev Med 2014; 62:96-102.

29. Parvatha Rani N, Neelambikai N. To study the effect of the body mass index and waist hip ratio on blood pressure in pre- and post-menopausal women. Int J Med Res Health Sci 2013;2:593-596.

30. Ambikairajah A, Walsh E, Tabatabaei-Jafari H, Cherbuin $\mathrm{N}$. Fat mass changes during menopause: a metaanalysis. Am J Obstet Gynecol 2019;221:393-409.

31. Youngmi E, Lee SN, Jung J, Kim MS, Moon KW, Yoo KD. Association between waist-hip ratio and coronary artery calcification in postmenopausal women. Menopause 2020;27:1010-1014.

32. Stenholm S, Harris TB, Rantanen T, Visser M, Kritchevsky SB, Ferucci L. Sarcopenic obesity: definition, cause and consequences. Curr Opin Clin Nutr Metab Care 2008; 11:693-700.
33. Norman K, Stobaus N, Gonzalez MC, Schulzke JD, Pirlich M. Hand grip strength: outcome predictor and marker of nutritional status. Clin Nutr 2011;30:135-142.

34. Li YZ, Zhuang HF, Cai SG, Lin CK, Wang PW, Yan LS et al. Low Grip Strength is a Strong Risk Factor of Osteoporosis in Postmenopausal Women. Orthop Surg 2018;10:17-22.

35. Kyu HH, Bachman VF, Alexander LT, Mumford JE, Afshin A, Estep $K$ et al. Physical activity and risk of breast cancer, colon cancer, diabetes, ischemic heart disease, and ischemic stroke events: systematic review and dose-response meta-analysis for the Global Burden of Disease Study 2013. BMJ 2013;354:3857.

36. Safdar A, Hamadeh MJ, Kaczor JJ, Raha S, Debeer J, Tarnopolsky MA. Aberrant mitochondrial homeostasis in the skeletal muscle of sedentary older adults. PLOS ONE 2010;5:10778

37. Goodpaster BH, Chomentowski P, Ward BK, Rossi A, Glynn NW, Delmonico MJ et al. Effects of Physical Activity on Strength and Skeletal Muscle Fat Infiltration in Older Adults: A Randomized Controlled Trial. J Appl Physiol 2008;105:1498-1503.

38. Trappe S, Godard M, Carroll C, Rowden G, Porter D. Resistance training improves single muscle fiber contractile function in older women. Am J Physiol Cell Physiol 2001;281:398-406.

39. Raue U, Slivka D, Minchev K, Trappe S. Improvements in whole muscle and myocellular function are limited with high-intensity resistance training in octogenarian women. J Appl Physiol 2009;106:1611-1617. 